\title{
OPEN A geostatistical approach to estimating source apportionment in urban and peri-urban soils using the Czech Republic as an example
}

Prince Chapman Agyeman ${ }^{\bowtie}$, Kingsley JOHN, Ndiye Michael Kebonye, Luboš Borůvka, Radim Vašát \& Ondřej Drábek

Unhealthy soils in peri-urban and urban areas expose individuals to potentially toxic elements (PTEs), which have a significant influence on the health of children and adults. Hundred and fifteen $(n=115)$ soil samples were collected from the district of Frydek Mistek at a depth of $0-20 \mathrm{~cm}$ and measured for PTEs content using Inductively coupled plasma-optical emission spectroscopy. The Pearson correlation matrix of the eleven relevant cross-correlations suggested that the interaction between the metal(loids) ranged from moderate $(0.541)$ correlation to high correlation $(0.91)$. PTEs sources were calculated using parent receptor model positive matrix factorization (PMF) and hybridized geostatistical based receptor model such as ordinary kriging-positive matrix factorization (OK-PMF) and empirical Bayesian kriging-positive matrix factorization (EBK-PMF). Based on the source apportionment, geogenic, vehicular traffic, phosphate fertilizer, steel industry, atmospheric deposits, metal works, and waste disposal are the primary sources that contribute to soil pollution in peri-urban and urban areas. The receptor models employed in the study complemented each other. Comparatively, OK-PMF identified more PTEs in the factor loadings than EBK-PMF and PMF. The receptor models performance via support vector machine regression (SVMR) and multiple linear regression (MLR) using root mean square error (RMSE), $R$ square $\left(R^{2}\right)$ and mean square error (MAE) suggested that EBK-PMF was optimal. The hybridized receptor model increased prediction efficiency and reduced error significantly. EBK-PMF is a robust receptor model that can assess environmental risks and controls to mitigate ecological performance.

Human-related activities such as industry, sewage discharge, mining, atmospheric deposition, and agriculture are primarily characterized by urban and peri-urban soil ${ }^{1}$. International communities, allied bodies, multinational companies, countries, and humans who are directly affected by potentially toxic elements (PTEs) worldwide have expressed great concern about the threat posed by PTEs. PTEs accumulations in the soil can cause changes in soil fertility and cultivation characteristics of bioavailability, as well as increase the persistence of PTEs toxicity, which can easily be transported and accumulated in a food chain, resulting in food safety hazards and healthrelated issues in the human body via a variety of pathways (inhalation, ingestion, and dermal uptake) ${ }^{2-4}$. Public quibble about the build-up of PTEs in farmland has been escalating, limiting the soil's functionality, creating crop and water toxicity, and endanger human health ${ }^{5,6}$. The impact of PTEs on the soil is a cross-border challenge that is not limited to a particular region but also a worldwide concern, which transcends peri-urban, urban and continental borders. Global integration, trade and movement of goods and services facilitate the impact of PTEs from afar on someone distant from a polluted place. Urban and rural areas, according to Kombe ${ }^{7}$ and Keshavarzi et al. ${ }^{8}$, are transitional areas where activities are integrated. This allows for easy accessibility of goods and services and migration of PTEs through torrential rainfall and erosion from urban and peri-urban areas and contrariwise. However, some big cities are expanding in order to incorporate a rising population in peri-urban areas $^{8}$ closer to urban areas. Though some cities are closer to peri-urban areas, it allows for easy congestion in 
the towns due to it being a hub for most multinational industries and people having the edge of migrating urban, increases vehicular traffic, creates an avenue for urban expansion and construction activities that contribute to soil pollution in the immediate environment.

According to Vázquez Cueva et al. ${ }^{9}$ and Tume et al. ${ }^{10}$, in many instances, urban waste, industrial effluents, and even manures and agricultural fertilizers pollute the soils of these locations with PTEs. Anthropogenic pollutants such as leaks and spills, manufacturing and construction activities, agricultural practices, transportation and chemical waste dumping, concomitant with natural pollutants, predominate in urban areas, gradually drifting to the peri-urban area as a result of land acquisition, industrial and urban expansion.

The uniqueness and dynamism of each urban and peri-urban area differ from one another geographically. However, the only constant is that PTEs are resident in the soil due to pollution, whether anthropogenic, natural, or both. Fei et al. ${ }^{11}$ and Huang et al. ${ }^{12}$ outlined that to minimize the cost and complexity of soil remediation effectively, it is critical to quantify the sources of soil PTEs pollution. The practicality of evidence-based analysis can be relished based on the robustness of the statistical approaches employed either qualitatively or quantitatively. Source apportionment approaches have been applied in multiple disciplines, including soil science, water research, and air quality assessment. Positive matrix factorization (PMF), absolute principal components scoremultiple linear regression (APCS-MLR), UNMIX, and chemical mass balance (CMB) are some of the multivariate statistics utilized in the quantification of source apportionment of pollutants. However, authors frequently apply the PMF, and APCS-MLR approaches to quantify source distribution. Lang et al. ${ }^{13}$; Jain et al. ${ }^{14}$; Guan et al. ${ }^{15}$; Salim et al. ${ }^{16}$; Zhang et al. ${ }^{17}$; Fei et al. ${ }^{4}$; Zhang et al. ${ }^{18}$ and Agyeman et al. ${ }^{19}$, are some of these authors that fall on the resilience of PMF and APCS-MLR to calculate source apportionment. The healthy academic nemesis between PMF and APCS-MLR has complemented each other in academic space. However, because the terrain (soil science) is so important, most authors sought to apply either one or both in source apportionment. Most comparative analyses, to name a few, Gholizadeh et al. ${ }^{20}$, Salim et al. ${ }^{16}$; Jain et al. ${ }^{14}$ and Guan et al. ${ }^{15}$ have adjudged PMF or APCS/MLR to be optimal. As summarized by Lee et al. ${ }^{21}$, the preference for PMF or APCS/MLR or both over the other receptor models based on the competitive advantage such as (i) the use of efficient monitoring processes, the establishment of a sizeable database which has become a general practice;(ii) these receptor models do not require pre-measured source profiles (i.e., backward tracking) in discrepancy with chemical mass balance (CMB); and (iii) the receptor model's capability permits it to cope with significant amounts of monitoring data. However, if the applicability of PMF or APCS/MLR or both has an advantage over other receptor models, its excellent performance is hampered by various limitations or constraints. According to Yuanan et al. ${ }^{22}$, PMF may produce inaccurate estimations if the PTEs identified in topsoil have undergone significant selection enrichment. Furthermore, Wu et al. ${ }^{23}$ and Guan et al. ${ }^{15}$ claimed that PMF was unable to effectively determine the nature of the differences in PTEs observed in surface soils across the entire area and create a fitting effect. Zhang et al. ${ }^{17}$ also added that APCS/MLR could not discharge a lot of sources in each factor loadings.

Investigating pollution sources pathways via diverse receptor models aids in controlling pollution hazards in the environment. The use of robust receptor models facilitates in minimizing the risk of pollution and, at the same time, can assist in assuaging occurrences. Essentially, the pathways of pollution sources may be identified using receptor models. The output obtained assists stakeholders in evaluating health and ecological impact and adopting actions to improve sustainability impact. The development of robust receptor models aids in detecting locations that require further attention and assists stakeholders in developing reliable emergency response plans. Wang et al. ${ }^{24}$ stressed that applying receptor models, which are based on multivariate statistical approaches to identify and quantify pollutants (PTEs) apportionment to their sources, can significantly improve the traditional source apportionment approach. This study intends to use PMF as a base model to build a hybridized receptor model that will enhance efficiency and minimize errors in identifying and estimating source apportionment. PMF will be combined with geostatistical approaches such as ordinary kriging and empirical Bayesian kriging. The study region is an active agricultural area with many industries such as metal works and steel industries. We hypothesized that the dependability of the receptor model is determined by its efficiency and ability to reduce error when applied. This study addresses the following research question: How reliable are the hybridized receptor models compared to the base model (PMF)? What is the performance of the receptor models in terms of efficiency and error reduction? The specific objectives of this paper revolve around the following: determining the concentration of PTEs in urban and peri-urban soil, comparing diverse receptor models for source apportionment, and proposing and validating receptor model technique that is efficient and more practical for source apportionment estimation.

\section{Materials and methods}

Research location (case study). The selected study area is in the Czech Republic in the Frydek Mistek district in the Moravian-Silesian area (Fig. 1). The research area's geomorphology is relatively rugged terrain, mostly part of the Moravian-Silesian Beskydy region, a part of the extracellular matrix mountain range. The study area is positioned at latitude $49^{\circ} 41^{\prime} 0^{\prime}$ North and longitude $18^{\circ} 20^{\prime} 0^{\prime}$ East at an altitude ranging from 225 to $327 \mathrm{~m}$ above sea level; however, the Koppen classification system of the area's climatic condition is classified as $\mathrm{Cfb}=$ temperate oceanic climate with a high level of rainfall even in dry months. The temperature fluctuates typically from -5 to $24^{\circ} \mathrm{C}$ throughout the year, with temperatures occasionally falling below $-14^{\circ} \mathrm{C}$ or reaching over $30^{\circ} \mathrm{C}$. The maximum average annual rainfall is $83 \mathrm{~mm}$, with a minimum total accumulation of $17 \mathrm{~mm}^{25}$. The district's area survey is estimated to be $1208 \mathrm{~km}^{2}$, with $39.38 \%$ of the land area under cultivation and $49.36 \%$ under forest cover. However, the site designated for the study is approximately $889.8 \mathrm{~km}^{2}$ (see Fig. 1). Agriculture, the steel industry, and metal works are all active in and around the Ostrava neighborhood. The soil qualities are easily distinguished from the color, texture, and carbonate concentration of the soil. The soil's texture is medium to fine, and it is derived from parent materials. They are primarily colluvial, alluvial, or aeolian in 


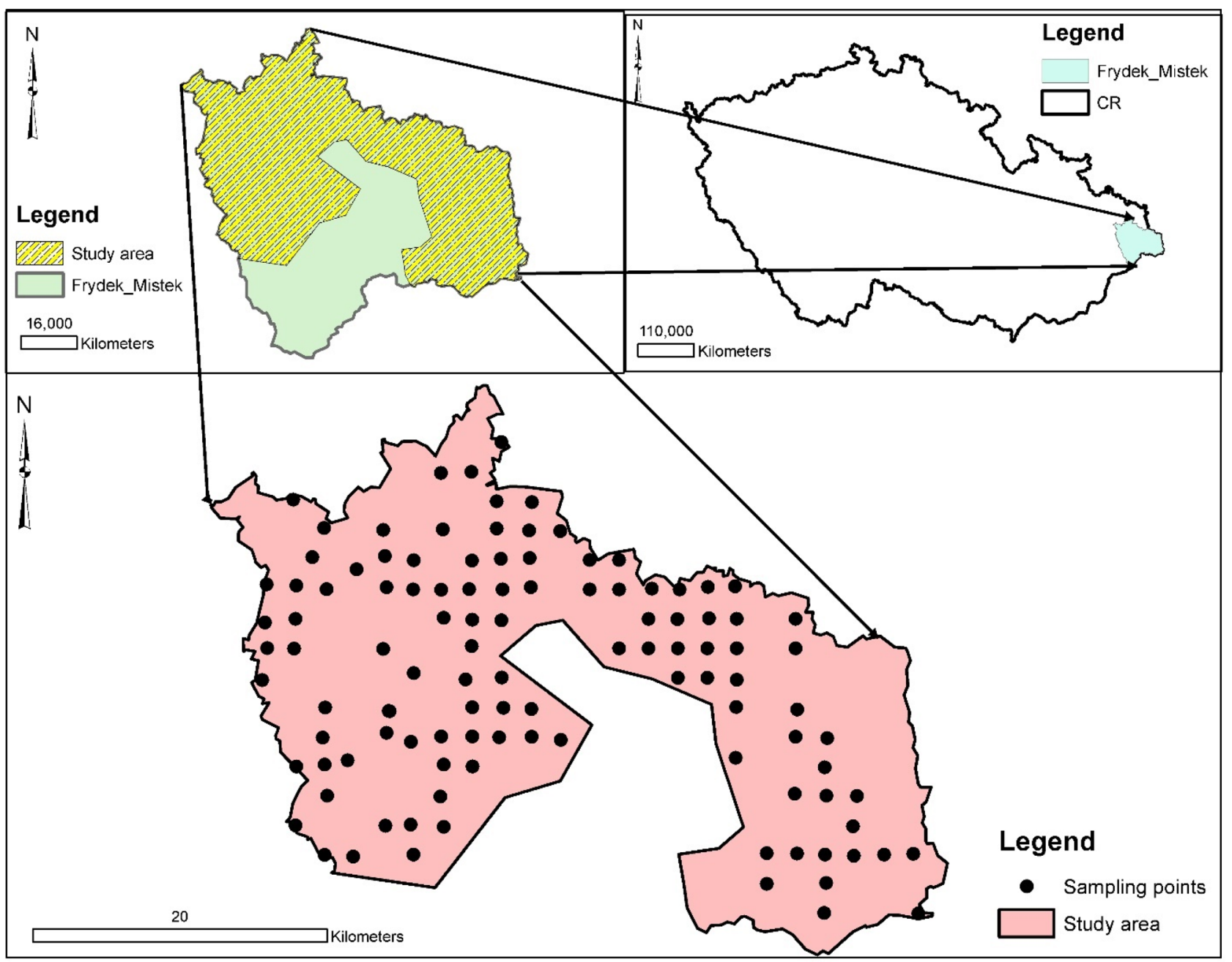

Figure 1. Study area.

nature. Some soil areas have mottles in the top and subsoil, which are usually followed by concrete and bleaching. However, cambisols and stagnosols are the most common soil types in the region ${ }^{26}$. With elevations ranging from 455.1 to $493.5 \mathrm{~m}$, cambisol soils predominate in the Czech Republic ${ }^{27}$.

Soil sampling and soil analysis. One hundred and fifteen topsoil samples were collected from urban and peri-urban areas in the Frydek Mistek district. The sample design used was the regular grid, and the soil sample intervals were $2 \times 2 \mathrm{~km}$ using a portable GPS unit (Leica Zeno 5 GPS) at a depth of 0 to $20 \mathrm{~cm}$ for topsoil. The samples were put in Ziploc bags, labelled correctly, and brought to the laboratory. To obtain a pulverized sample, the samples were air-dried, crushed by a mechanical device (Fritsch disk mill), and sieved $(<2 \mathrm{~mm})$. One gram of the dried, homogenized, and sieved soil sample (sieve size $2 \mathrm{~mm}$ ) was placed in a labelled Teflon bottle. In each Teflon bottle, $7 \mathrm{ml}$ of $35 \% \mathrm{HCl}$ and $3 \mathrm{ml}$ of $65 \% \mathrm{HNO}_{3}$ were dispensed (using automatic dispensers-one for each acid). The cap was gently closed to allow the sample to remain overnight for reaction (aqua regia procedure). Subsequently, the supernatant was placed on a hot metal plate for $2 \mathrm{hrs}$ to boost the digestion process of the sample before being allowed to cool. Then, the supernatant was transferred to a $50 \mathrm{ml}$ volumetric flask and diluted to $50 \mathrm{ml}$ with deionized water. After that, the diluted supernatant was filtered into $50 \mathrm{ml}$ PVC tubes.

Furthermore, $1 \mathrm{ml}$ of the diluted solution was diluted with $9 \mathrm{ml}$ of deionized water and filtered into a $12 \mathrm{ml}$ test tube prepared for PTE (Al. Ba, Cd, Pb, Sb, Fe. V) pseudo-concentration. ICP-OES (inductively coupled plasma optical emission spectrometry) (Thermo Fisher Scientific, USA) was used to detect metal concentrations in accordance with conventional methods and protocols. The quality assurance and control (QA/QC) method was ensured by examining each sample's standards reference material (SRM NIST 2711a Montana II soil). The detection limits of the PTEs used in this investigation are as follows: $0.0002(\mathrm{Cd}), 0.0007(\mathrm{Cr}), 0.0060(\mathrm{Cu})$, $0.0001(\mathrm{Mn}), 0.0004(\mathrm{Ni}), 0.0015(\mathrm{~Pb}), 0.0067(\mathrm{As})$, and 0.0060. (Zn). To accomplish QA/QC, we used blank reagents, repeated samples, and standard reference materials. Duplicate analysis was performed to guarantee that the error was minimized $(<5 \%)$.

Receptor models. PMF receptor model. Positive matrix factorization (PMF) receptor modelling is often performed with the US-EPA PMF 5.0 software ${ }^{28}$. The receptor model is one of the multivariate approaches for 
source analysis used to solve the chemical mass balance, and the original data matrix $\mathrm{X}$ is represented in the order $m \times n$, which can be written as

$$
X=G F+E
$$

$\mathrm{G}(\mathrm{m} \times \mathrm{p})$ represents a factor contribution matrix, $\mathrm{F}(\mathrm{p} \times \mathrm{n})$ also denotes the factor profile matrix, and $\mathrm{E}(\mathrm{m} \times \mathrm{n})$ is a residual error matrix. $E$ is given as

$$
e_{i j}=\sum_{k=1}^{p} g_{i k} f_{k i}-x_{i j}
$$

where $i$ is the elements 1 to $m, j$ signifies elements 1 to $n$, and $k$ represents the source from 1 to $p$. The authors have previously discussed the function of the minimal $Q$ and the uncertainty, and the parameters and implementation techniques involved ${ }^{19}$.

Ordinary kriging - positive matrix factorization $(O K-P M F)$. Ordinary kriging $(\mathrm{OK})$ is an interpolation approach that allowed us to estimate the spatial distribution of PTEs in the site under investigation. Kriging is an interpolation that predicts variable values in areas where data are unavailable based on the spatial pattern of the existing data $^{29}$. The equation is expressed as

$$
\mathrm{Z}^{\prime}\left(x_{0}\right)=\sum_{i=1}^{n} \lambda_{i} \cdot \mathrm{Z}\left(x_{i}\right)
$$

It can be computed by the semi-variance function of the variables on the condition that the estimated value is unbiased and optimal. The semivariogram model is expressed as:

$$
\gamma(h)=\frac{1}{2 N(h)} \sum_{i=1}^{n}\left[Z\left(X_{i}\right)-Z\left(X_{i}+h\right)\right]^{2}
$$

whereby $\gamma(h)$ signifies semi-variance, $N(h)$ denotes point group number at distance $h, Z\left(x_{i}\right)$ represents numerical value at position $x_{i}$, and $\mathrm{Z}\left(\mathrm{x}_{\mathrm{i}}+\mathrm{h}\right)$ is the numerical value at a distance $\left(\mathrm{x}_{\mathrm{i}}+\mathrm{h}\right)$.

However, the hybridized (OK-PMF) equation between PMF and OK is given as

$$
\mathrm{Z}^{\prime}\left(x_{0}\right)_{i j}=\sum_{i=1}^{n} \lambda_{i} \cdot \mathrm{Z}\left(x_{i}\right)_{i j}
$$

In which $Z^{\prime}\left(x_{0}\right)_{i j}$ is the interpolated value for point $x_{0}$ of each PTEs from the kth source in the ith sampling location, $Z\left(x_{i}\right)_{i j}$ denotes a known value of the concentration of the single PTE in the soil in the jth source from the ith sampling site, and $\lambda_{\mathrm{i}}$ represent the kriging weight for the $\mathrm{Z}\left(x_{\mathrm{i}}\right)$ values.

The OK-PMF receptor model application is based on interpolated data points from all PTE data points observed. Predicted data from OK interpolation is retrieved and then fed into the US-EPA PMF 5.0 software for source contribution computation to estimate the PTE source distribution. The traditional PMF method uses raw data, but the OK-PMF approach uses predicted data after OK interpolation.

Empirical Bayesian kriging-positive matrix factorisation (EBK-PMF). Empirical Bayesian kriging (EBK) is one of the numerous geostatistical interpolation techniques used in modelling in diverse fields such as soil science. Unlike the other kriging interpolation techniques, EBK varies from conventional kriging methods by considering the error of the semi variogram model estimation ${ }^{30}$. In EBK interpolation, several semi variogram models are calculated during the interpolation instead of a unitary semi variogram. The interpolation technique makes way for associated uncertainties, thereby plotting semi variogram and programming the highly complex parts to compose a good kriging approach ${ }^{31}$. The interpolation process of EBK follows three criteria as proposed by Krivoruchko ${ }^{30}$, (a) the model estimate semi variogram from the input dataset (b) based on the generated semi variogram a new predicted value is assigned to each inputted dataset location and (c) finally a model is computed from the simulated dataset. The Bayesian equation rule is giving as posterior

$$
\operatorname{Prob}(A, B)=\sum \operatorname{Prob}(A) \times \frac{\operatorname{Prob}(B / A)}{\operatorname{Prob}(B)}
$$

The semi variogram calculation is based on the Bayes rule, which indicates that the semi variogram may generate the observed dataset. Krivoruchko ${ }^{30}$ explains that, during the computation of semivariogram in step 1, a set of data is utilized to stimulate a new location input; however, steps 2 and 3 are replicated.

Nonetheless, the hybridized (EBK-PMF) equation between PMF and EBK is given as

$$
\operatorname{Prob}(A, B)_{i j}=\sum \operatorname{Prob}(A) \times \frac{\operatorname{Prob}(B / A)_{i j}}{\operatorname{Prob}(B)_{i}}
$$

where the $\operatorname{Prob}(A, B)_{i j}$ represents the posterior probability of the computed PTEs from the kth source in the ith sampling location, $\operatorname{Prob}(A)$ represent the prior probability, $\operatorname{Prob}(B, A)_{i j}$ denotes the likelihood of the concentration of the single PTE in the soil in the jth source from the ith sampling site and the $\operatorname{Prob}(B)_{i}$ also signifies the 
marginal probability. The EBK-PMF receptor model application is based on interpolated data points from all observed PTE data points. To estimate the PTE source distribution, predicted data from EBK interpolation is retrieved and then inserted into the US-EPA PMF 5.0 software for source contribution computation. The traditional PMF approach uses raw data, but the hybridized EBK-PMF uses predicted data after EBK interpolation.

Geographically weighted ordinary regression (GWR-OLS). Geographically weighted regression (GWR) advances the well-known regression architecture by predicting a set of parameters for any range of locations throughout a study region instead of a single collection of parameters. Four environmental covariates (i.e., elevation, total catchment area, LS factor and valley depth) were extracted and used to fit a GWR-OLS model to predict the distribution of PTEs in each factor loading based on the factors scores obtained from each receptor model. In the first place, each equation (elevation, total catchment area, LS factor, and valley depth) was optimized using the GWR.sel function from the spgwr R package. Subsequently, the GWR function was applied to fit the GWR-OLS depending on the bandwidth determined by the previous function. Brunsdon et al. ${ }^{32}$ provide detailed descriptions of the GWR-OLS. Zhang et al. ${ }^{33}$; Kumar et al. ${ }^{34}$; Wang et al. ${ }^{35}$; Song et al. ${ }^{36}$; Zeng et al..$^{37}$ and Wang et al. $^{38}$ are only a few of the soil-based research that has effectively used the GWR-OLS for various reasons. The predicted factor scores data from GWR-OLS were then kriged to generate a geographical weighted regression kriging spatial distribution map for the factor scores of each receptor model.

Data modelling techniques. Support vector machine regression (SVMR). SVM is a machine learning algorithm that develops an optimal disengaging hyperplane to separate categories with similarities but is not linearly independent. Vapnik ${ }^{39}$, created the technique for classification reasons; however, it has recently been used to solve regression-oriented problems. According to Li et al. ${ }^{40}$, SVM is one of the best classifier approaches and has been used in a variety of fields. The regression aspect of SVM is used in this study (support vector machine regression-SVMR). Cherkassky and Mulier ${ }^{41}$, pioneered SVMR as a regression based on a kernel, and its computation was performed using a linear regression model with a multinational space feature. However, according to John et al. ${ }^{42}$ the SVMR modelling employs a hyperplane linear regression, which generates a nonlinear relationship and allows for the space feature. Vohland et $\mathrm{al}^{43}$, suggested that epsilon $(\varepsilon)$-SVMR uses a trained dataset to obtain a represented model as an epsilon -insensitive feature utilized to map data independently with the optimum epsilon- $\varepsilon$ departure from dependent data training.

The preset distance error inside is ignored from the actual value, and if the error is larger than the epsilon $(\varepsilon)$, the soil attribute compensates for it. In addition, the model decreases the complexity of training data to a broader subset of support vectors. The equation as proposed by Vapnik ${ }^{39}$, is given as

$$
y(x)=\sum_{k=1}^{N} \alpha_{k} K\left(x, x_{k}\right)+b,
$$

In which the b represents the scalar threshold, $K\left(x, x_{k}\right)$ representing the kernel function, $\alpha$ denoting the Lagrange multiplier, $\mathrm{N}$ symbolizing the number dataset, $x_{k}$ representing the data input, and $y$ is the data output. One of the critical kernels used is the SVMR operation with the Gaussian Radial Basis Function (RBF). The RBF kernel was applied to ascertain the optimum SVMR model that is essential to procure the finest penalty set factors C and the kernel parameters gamma $(\gamma)$ for the PTEs training data. We assessed the set of training and then tested the validation set's model performance. The application of SVMR is simple. When compared to other regression approaches, SVMR requires less computing. Furthermore, SVMR employs multiple classifiers that have been trained on various types of data using probability principles.

Multiple linear regression. The multiple linear regression (MLR) model is a regression model that encapsulates the relationship between a response variable and numerous predictor variables by employing linearly inserted parameters that are computed using the least-squares approach. In MLR, the least square model is a prediction function that is directed toward a soil attribute following the selection of an explanatory variable. The PTEs was used as the response variables, which was used to establish the linear relationship utilizing the explanatory variable. The MLR equation is given as

$$
y=a+\sum_{i-1}^{n} b_{1} \mathrm{X} x_{i} \pm \varepsilon_{i}
$$

In which y represents the response variable, a denotes the intercept, $\mathrm{n}$ signifies the number of predictors, $b_{1}$ denotes the partial regression of coefficient, $x_{i}$ implies the predictors or the explanatory variables and the $\varepsilon_{i}$ signifies the error in the model, which is also called residual.

The model was utilized in $\mathrm{R}$ ( $\mathrm{K}=10$ folds cross-validation, which is repeated five times). MLR can calculate the relative relevance of one or multiple predictor differences in proportion to the significance value. MLR refers to the ability to identify outliers or irregularities.

Data partitioning. The number of samples used in the modelling approaches was 115, and a random approach was used to divide the data into a test dataset (with $25 \%$ for validation) and a training dataset (75\% for calibration). The training dataset was used to calibrate the regression models, while the test dataset was utilized to assess generalization capabilities ${ }^{44}$. This was done to evaluate the suitability of the various models used to estimate PTE source apportionment. All the models were put through a 10-fold cross-validation process and it 


\begin{tabular}{|c|c|c|c|c|c|c|c|}
\hline \multirow[b]{2}{*}{ Elements } & Mean & S.D.* & Coef. Var. ${ }^{\S}$ & Minimum value & Maximum value & WAV $^{*}$ & $\mathbf{E A V}^{\Subset}$ \\
\hline & \multicolumn{7}{|l|}{$\mathrm{mg} / \mathrm{kg}$} \\
\hline $\mathrm{Al}$ & $13,251.08$ & 3485.04 & 26.3 & 6284.59 & $27,709.33$ & - & - \\
\hline $\mathrm{Ba}$ & 79.46 & 40.83 & 51.38 & 29.8 & 265.66 & 460 & 400 \\
\hline $\mathrm{Fe}$ & $20,054.95$ & 9942.49 & 49.58 & 8650.32 & $79,901.24$ & - & - \\
\hline $\mathrm{Sb}$ & 2.61 & 1.08 & 41.33 & 2.26 & 9.72 & 0.67 & 1.04 \\
\hline $\mathrm{V}$ & 31.37 & 9.35 & 29.81 & 15.61 & 81.86 & 129 & 68 \\
\hline $\mathrm{Cd}$ & 1.84 & 1.01 & 55.14 & 0.61 & 7.28 & 0.14 & 0.28 \\
\hline $\mathrm{Pb}$ & 33.86 & 18.51 & 54.68 & 9.56 & 155.69 & 27 & 32 \\
\hline \multicolumn{8}{|c|}{ Environmental covariates } \\
\hline Elevation & 378.36 & 93.55 & 24.72 & 240.33 & 902.11 & - & - \\
\hline Total Catchment Area & $335,276.61$ & $1,512,375.8$ & 451.08 & 984.56 & $12,617,766.68$ & - & - \\
\hline LS-Factor & 1.29 & 1.66 & 129.06 & 0.01 & 13.08 & - & - \\
\hline Valley Depth & 220.12 & 57.74 & 26.23 & 25.73 & 351.13 & - & - \\
\hline
\end{tabular}

Table 1. Statistical summary of sampled data. ${ }^{*}$ Standard deviation, ${ }^{\$}$ coefficient of variability, ${ }^{*}$ world average value and ${ }^{\circledR}$ European average value ${ }^{85}$.

was repeated five times. To predict the targeted variables, the factor contributions for each receptor model were employed as predictors or explanatory variables. All the modelling regimes were performed in a RStudio.

Accuracy assessment and validation. While evaluating the model's accuracy and its validation, validation criteria were used to establish the best and most optimal model fitting for the computation of source distribution based on geostatistical assessment-based positive matrix factorization receptor models. The receptor models were assessed utilizing mean absolute error (MAE), root mean square error (RMSE), and R square, or coefficient determination $\left(R^{2}\right)$. $R^{2}$ illustrates the variation of the percentage in the response and is expressed by the regression model. The RMSE and the size of the variability within the independent measurement characterize the model prediction capability, while MAE establishes the true measurable value. The $\mathrm{R}^{2}$ value ought to be high to establish the optimum receptor model using the validation criteria, and the closer the value is to 1 , the higher the accuracy. Corresponding to $\mathrm{Li}$ et al. ${ }^{45}, \mathrm{R}^{2}$ criteria value of 0.75 or less is considered a satisfactory prediction and above 0.75 is a good prediction. Methods for assessing validation requirements utilizing RMSE and MAE, with a lower obtained value being appropriate and ideal for model selection. The following equation describes the validation procedures.

Mean absolute error.

$$
M A E=\frac{1}{n} \sum_{i=1}^{n} Y_{i}-\hat{Y}_{i}
$$

R square.

$$
\mathrm{R}^{2}(\%)=1-\frac{\sum\left(\mathrm{Y}_{\mathrm{i}}-\hat{\mathrm{Y}}_{\mathrm{i}}\right)^{2}}{\sum\left(\mathrm{Y}_{\mathrm{i}}-\hat{\mathrm{Y}}_{\mathrm{i}}\right)^{2}}
$$

Root mean square error.

$$
\operatorname{RMSE}(m g / k g)=\sqrt{\frac{1}{n} \sum_{i=1}^{n}\left(\hat{Y}_{i}-Y_{i}\right)^{2}}
$$

whereby $\mathrm{n}$ represents the size of the observations $Y_{i}$ represents the measured response and the $\hat{Y}_{i}$ also stated as the predicted response values, accordingly, for the ith observation term.

Data analysis. The R studio was used to perform correlation matrix, support vector machine regression, multiple linear regression and the geographically weighted ordinary regression. Ordinary kriging and empirical Bayesian kriging were interpolated in ArcGIS.

\section{Results and discussion}

Data description. The statistical description of the geometric mean concentration of the PTEs in the study area is shown in Table 1. According to the estimated coefficients of variation (CV) of the PTEs, the CV of Ba, Cd, and $\mathrm{Pb}$ surpassed 50\% (see Table 1), implying that the sampled data are highly variable and non-homogeneous 


\section{Ranked Cross-Correlations}

\section{1 most relevant}

口

.25

.5

.75

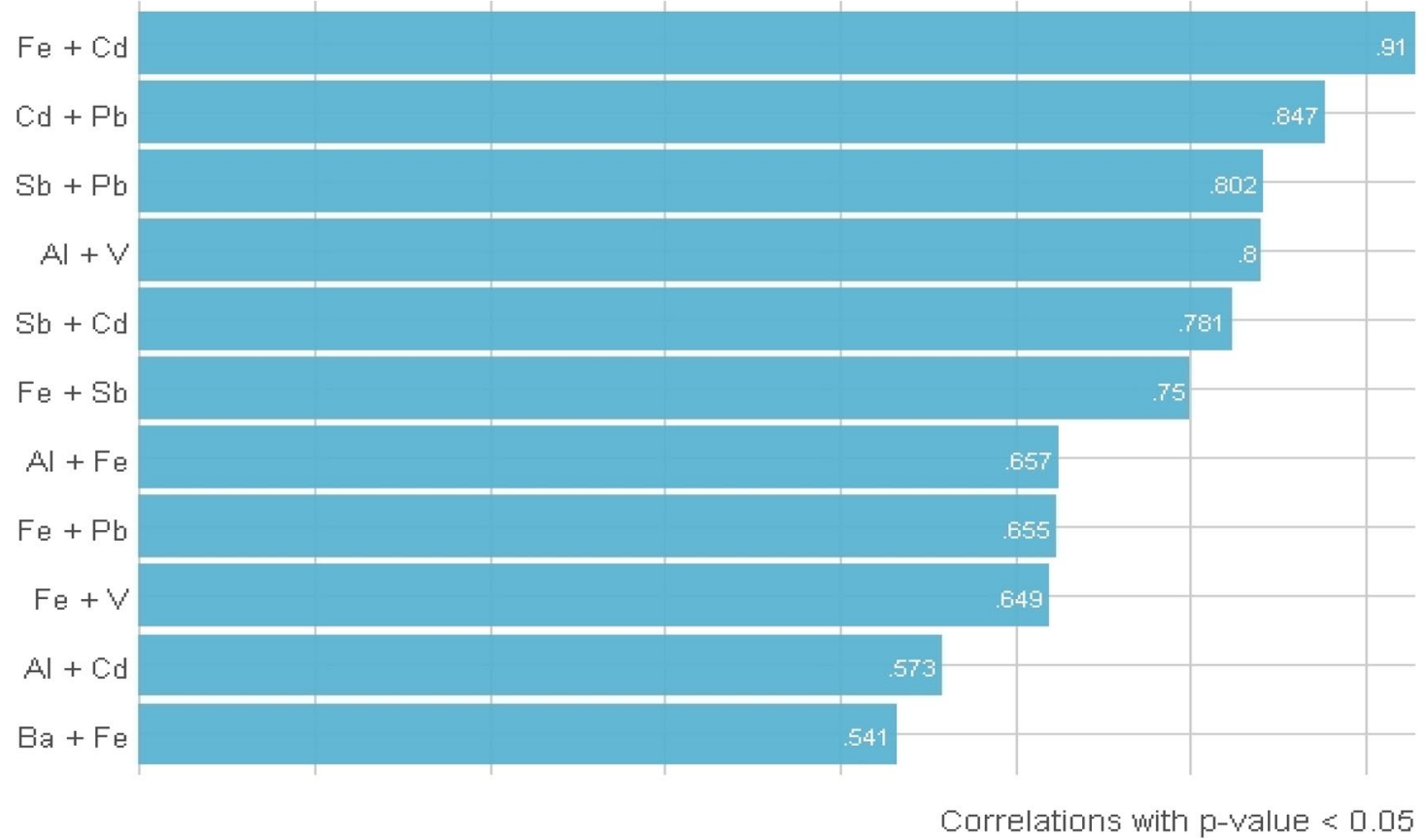

Figure 2. Interaction of PTEs using Pearson correlation matrix.

pollution caused by anthropogenic activities. In contrast, the $\mathrm{CV}$ of the following PTEs $\mathrm{Al}, \mathrm{Fe}, \mathrm{Sb}$, and $\mathrm{V}$ was less than $50 \%$, indicating moderate variability and implying that the PTEs data is more homogeneously distributed. The standard deviation (SD) values obtained for each PTE exceeded one. They were relatively high due to the high values of some of the PTEs, implying that the PTEs are highly variable. The minimum and maximum values of the PTEs ranges between 6284.59 and $27,709.33 \mathrm{mg} / \mathrm{kg}(\mathrm{Al}), 29.80-265.66 \mathrm{mg} / \mathrm{kg}(\mathrm{Ba}), 8650.32-79,901.24 \mathrm{mg} /$ $\mathrm{kg}(\mathrm{Fe}), 2.26-9.72 \mathrm{mg} / \mathrm{kg}(\mathrm{Sb}), 15.61-81.86 \mathrm{mg} / \mathrm{kg}(\mathrm{V}), 0.61-7.28 \mathrm{mg} / \mathrm{kg}(\mathrm{Cd})$ and $9.56 \mathrm{mg} / \mathrm{kg}$ to $155.69 \mathrm{mg} / \mathrm{kg}$ $(\mathrm{Pb})$. The minimum and maximum values for the environmental covariates were 240.33-902.11 for elevation, 984.56-12,617,766.68 for total catchment area, 0.01-13.08 for LS factor, and valley depth 25.73-351.13. The geometric mean concentration of $\mathrm{Sb}, \mathrm{Cd}$ and $\mathrm{Pb}$ were found to be higher than the geochemical background level of both the world average values (WAV) and the European average values (EAV). The current study's antimony $(\mathrm{Sb})$, cadmium $(\mathrm{Cd})$, and lead $(\mathrm{Pb})$ concentration levels were found to be 3.89, 13.14, and 1.25 times higher than the WAV threshold, and 2.50, 6.57, and 1.05 times higher than the EAV threshold, respectively. However, the geometric mean concentration of barium $(\mathrm{Ba})$ and vanadium was below the geochemical threshold level of both WAV and EAV. The geometric mean of Cd in the current study was found to be higher when compared to the peri-urban soil of southeast China ${ }^{1,46}$. The geometric mean concentration of $\mathrm{Fe}, \mathrm{Pb}$, and $\mathrm{Sb}$ reported by Hossain Bhuiyan et al. ${ }^{47}$ (Dhaka [Fe 12,232 mg/kg]), Linde et al. ${ }^{48}$ (Sweden[Pb- $\left.30 \mathrm{mg} / \mathrm{kg}\right]$ ), Tume et al. ${ }^{49}$ (Chile $[\mathrm{Pb}-19.8 \mathrm{mg} / \mathrm{kg}]$ ),Wiseman et al. $^{50}$ (University of Toronto Canada[Sb-0.68 kg/mg]) and De Miguel et al. ${ }^{51}$ (Madrid[Sb-1.01 mg/kg]) were found to be lower than the geometric mean concentrations of $\mathrm{Fe}, \mathrm{Pb}$, and $\mathrm{Sb}$ in the current study. Nadal et al. ${ }^{52}$ reported a low vanadium concentration of $19.3 \mathrm{mg} / \mathrm{kg}$ in an industrial area and $13.6 \mathrm{mg} / \mathrm{kg}$ in the residential area of Tarragona County, Spain, which was lower than the $\mathrm{V}$ concentration in the current study. Da Silva et al. ${ }^{53}$ reported low Ba concentration measured in five cities in Florida State (USA) such as Clay County $(23.4 \mathrm{mg} / \mathrm{kg})$, Orlando $(20.3 \mathrm{mg} / \mathrm{kg})$, Pensacola $(48.1 \mathrm{mg} / \mathrm{kg})$, Tampa $(23.7 \mathrm{mg} / \mathrm{kg})$ and West Palm Beach $(29.1 \mathrm{mg} / \mathrm{kg})$. In Thonburi in Bangkok, the geometric mean of Al measured in the urban soil was $13,800 \mathrm{mg} / \mathrm{kg}^{54}$, which was a bit higher than the mean concentration of $\mathrm{Al}$ measured in the current study. This implies that Thonburi, Bangkok, is inundated with more industrial activities that pollute the urban soil than the current study area.

Pearson correlation matrix (PCM) of the PTEs. The metallic association among PTEs was identified using PCM to navigate metadata on the metallic pathways of the elements via their sources (see Fig. 2). The computed PCM revealed eleven optimal associations between the PTEs from moderate to high metallic strength. Cadmium exhibited a high correlation with $\mathrm{Fe}, \mathrm{Pb}$, and $\mathrm{Sb}$, with $\mathrm{r}$ values of $0.91,0.847$ and 0.781 . The significant metallic nature of $\mathrm{Cd}$ and $\mathrm{Pb}(\mathrm{r}=0.847)$ reflects a geochemical tendency that is most likely related to the use of fertilizers and pesticides. This is congruent with the findings of Zhang et al. ${ }^{55}$ who reported that pesticides and fertilizers are most likely input sources for the $\mathrm{Cd}$ and $\mathrm{Pb}$ relationship. Cadmium and iron are industrially related due to steel and iron industries as well as non-ferrous metal production. According to Ursnyová and Hladková ${ }^{56}$, 


\begin{tabular}{|l|l|l|r|r|r|r|r|r|r|r|r|r|}
\hline & \multicolumn{9}{|l}{ EBK-PMF } & \multicolumn{1}{l|}{ OK-PMF } & PMF \\
\cline { 2 - 14 } & F1\% & F2\% & F3\% & F4\% & F1\% & F2\% & F3\% & F4\% & F1\% & F2\% & F3\% & F4\% \\
\hline $\mathrm{Al}$ & 27.70 & 15.70 & 36.90 & 19.70 & 13.00 & 40.40 & 5.70 & 40.80 & 20.60 & 54.70 & 23.80 & 1.00 \\
\hline $\mathrm{Ba}$ & 23.60 & 41.70 & 32.90 & 1.80 & 42.40 & 0.30 & 17.20 & 40.20 & 53.23 & 6.56 & 6.70 & 18.00 \\
\hline $\mathrm{Cd}$ & 11.90 & 22.80 & 11.10 & 54.10 & 46.20 & 41.00 & 12.20 & 0.60 & 0.50 & 49.10 & 13.30 & 37.20 \\
\hline $\mathrm{Fe}$ & 11.00 & 27.30 & 27.60 & 34.00 & 45.60 & 25.90 & 12.90 & 15.60 & 15.80 & 48.50 & 19.90 & 15.80 \\
\hline $\mathrm{Pb}$ & 41.90 & 17.70 & 0.00 & 40.40 & 0.00 & 40.20 & 59.80 & 0.00 & 0.00 & 29.50 & 20.60 & 49.90 \\
\hline $\mathrm{Sb}$ & 27.60 & 20.10 & 28.00 & 24.30 & 31.90 & 17.90 & 27.90 & 22.20 & 14.30 & 17.90 & 48.20 & 19.60 \\
\hline $\mathrm{V}$ & 27.80 & 18.60 & 40.10 & 13.40 & 10.30 & 34.50 & 9.50 & 45.70 & 23.40 & 50.40 & 26.20 & 0.00 \\
\hline
\end{tabular}

Table 2. Proportional contribution of each factor (F) for PTEs derived from receptor models.

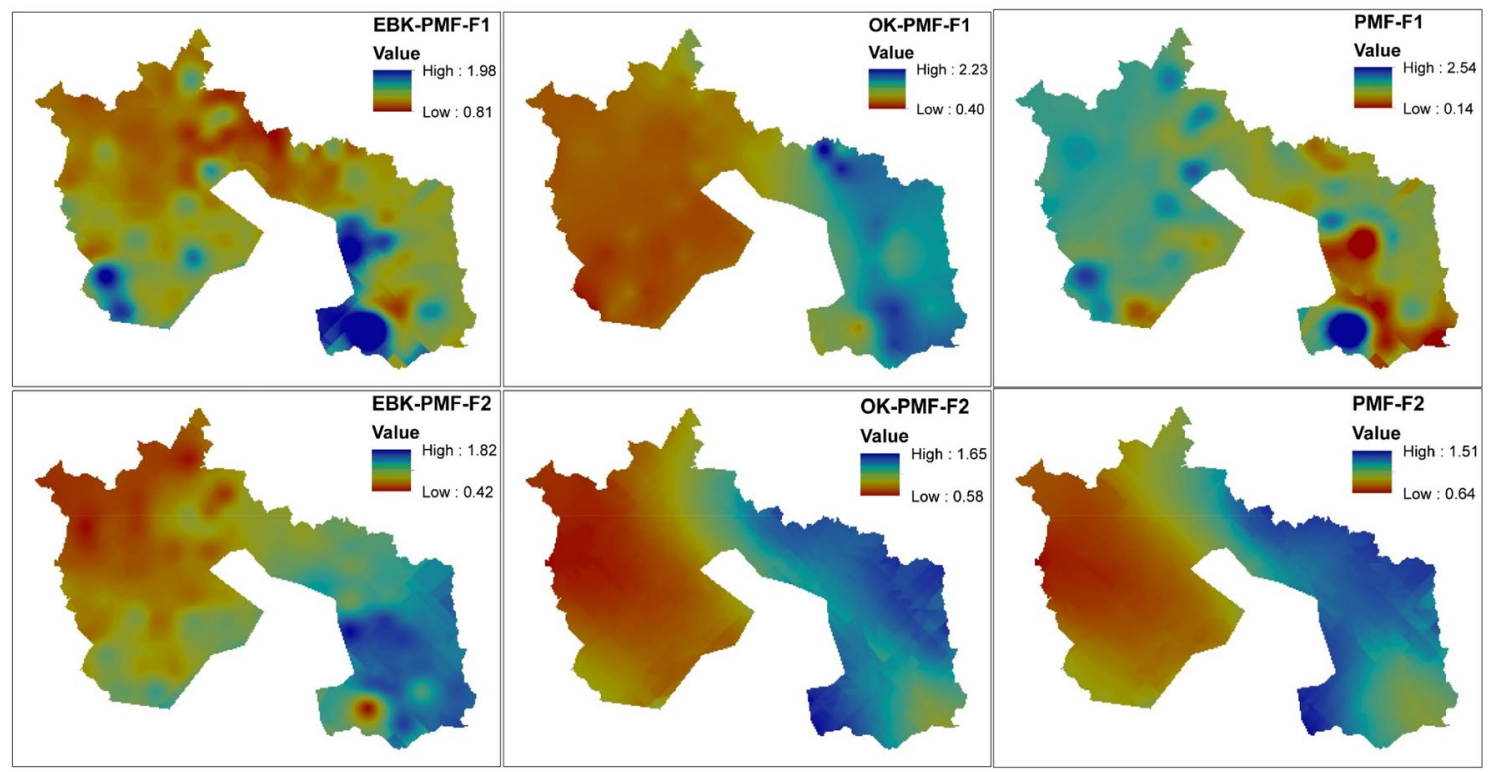

Figure 3. Spatial prediction of receptor model factor scores using geographically weighted regression kriging [Created in ArcGIS version 10.7 [The spatial distribution maps was created with ArcGIS Desktop (ESRI, Inc, Version 10.7, URL: https://desktop.arcgis.com)].

the emission of $\mathrm{Cd}$ to the atmosphere that precipitates on the soil surface is mostly caused by the steel, iron, and non-ferrous metal industries. However, Sb showed strong nexus with $\mathrm{Pb}$ and $\mathrm{Cd}$ with $\mathrm{r}$ value $=0.802$ and 0.781 , respectively. These PTEs $\left(\mathrm{Sb}, \mathrm{Cd}\right.$, and $\mathrm{Pb}$ ) have a close relationship in the battery manufacturing industry ${ }^{57}$. Aluminum ( $\mathrm{Al})$ and Vanadium $(\mathrm{V})$ are also strongly associated with $\mathrm{r}$ value $=0.80 . \mathrm{Al}$ and $\mathrm{V}$ share the same source, according to Negri et al. ${ }^{58}$ and Harford et al. ${ }^{59}$, which is wastewater discharged from alumina refineries. Nevertheless, other PTEs such as $\mathrm{FeV}, \mathrm{FeBa}, \mathrm{FePb}, \mathrm{AlFe}$ and AlCd also exhibited moderate relationship amongst each other with $r$ values $=0.649,0.541,0.655,0.657$ and 0.573 respectively. Sedimentary ironstone that is rich in $\mathrm{Fe}$ oxide and contained a considerable amount of an iron ore compound from which iron $(\mathrm{Fe})$ may be smelted economically and is defined to contain a large amount of Fe oxides is frequently deposited with $\mathrm{Pb}, \mathrm{V}$, and $\mathrm{Ba}$ in high concentration ${ }^{60}$. Based on their correlation, the correlation between $\mathrm{Al}$ and $\mathrm{Fe}$ is lithogenic, but the relationship between $\mathrm{Al}$ and $\mathrm{Cd}$ is more of a crustal origin ${ }^{61}$.

Source identification and contribution. The EPA-PMF version 5.0 was the software used to detect the source and compute the percentage contribution of each PTEs in each factor loadings. The accuracy of the analysis was guaranteed based on the minimum Q that controls the residual values $\mathrm{E}$. The analytical process had to run 20 times to choose the best run that best fits data processed with a minimal Q value. Run 12 was deemed appropriate for this study, and four factors' loadings were discharged when all the runs converged (i.e., is signaling Yes). For a PTE to be deemed to have controlled a factor, the minimum percentage figure was fixed at $40 \%$. Table 2 and Figs. 3, 4 and 5 indicate the percentage factorial contribution and spatial distribution of the geographical variation of the loaded PTEs in each factor per receptor model.

Factor 1 of the EBK-PMF receptor model accounted for $24.51 \%$ of the total variance in the factor loadings. On the other hand, OK-PMF and PMF receptor models accounted for $27.06 \%$ and $18.67 \%$ factor loadings, respectively. $\mathrm{Pb}(41.90 \%)$ dominated EBK-PMF, Cd (46.20\%), Ba (42.40\%), and $\mathrm{Fe}$ (45.60\%) controlled OK-PMF, and $\mathrm{Ba}(53.23 \%)$ monopolized PMF (see Table 2). The distribution of PTEs in factor 1 of various receptor models 


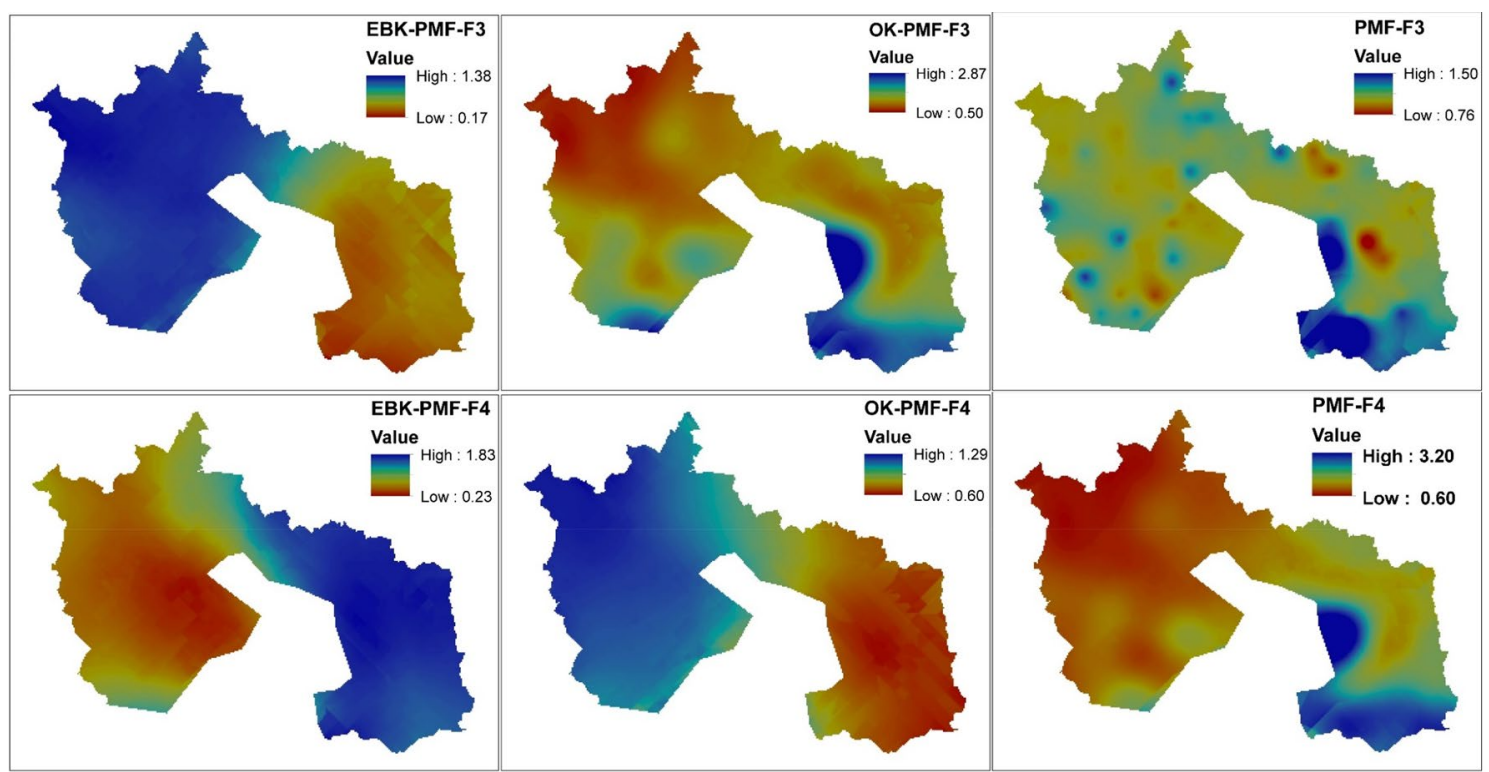

Figure 4. Spatial prediction of receptor model factor scores using geographically weighted regression kriging [The spatial distribution maps was created with ArcGIS Desktop (ESRI, Inc, Version 10.7, URL: https://desktop. arcgis.com)].
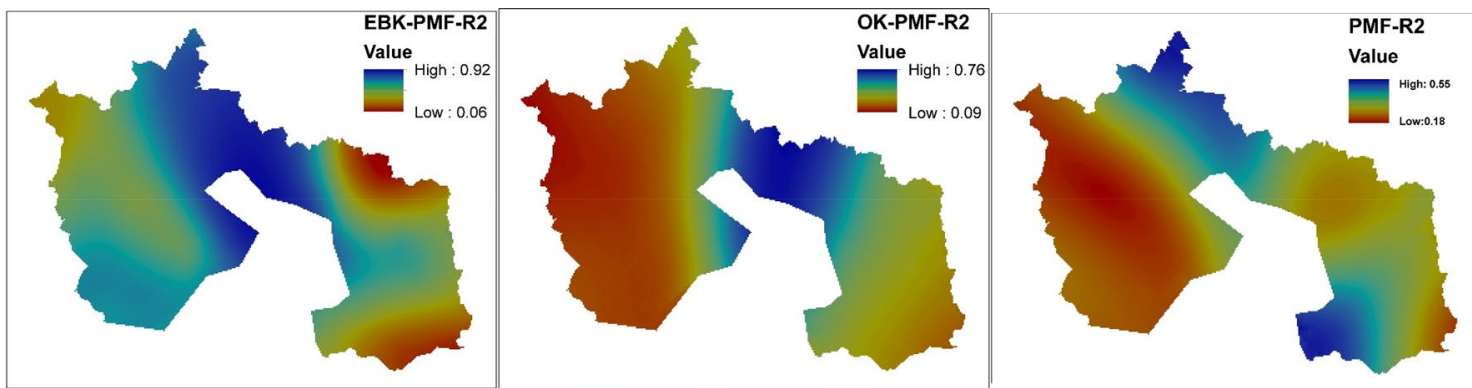

Figure 5. Spatial prediction of receptor model factor scores coefficient of determination $\left(\mathrm{R}^{2}\right)$ using geographically weighted regression kriging [The spatial distribution maps was created with ArcGIS Desktop (ESRI, Inc, Version 10.7, URL: https://desktop.arcgis.com)].

suggested that $\mathrm{Pb}$ from the EBK-PMF and $\mathrm{Cd}$ from the $\mathrm{OK}-\mathrm{PMF}$ are primarily anthropogenic in provenance. However, Ba from the PMF receptor model is more of a geogenic origin. Preceding studies by Ye et al. ${ }^{62}$; Ying et al. ${ }^{63}$ and Zhang et al. ${ }^{64}$ have suggested unequivocally that the excess of $\mathrm{Pb}$ and $\mathrm{Cd}$ in urban and peri-urban soil might be pollution emanating from vehicular traffic and other human activities such as particulate matter. According to a study conducted by Reitner and Thiel ${ }^{65}$, gasoline $\mathrm{Pb}$ additives were the principal source of $\mathrm{Pb}$ in the European atmosphere, which was deposited on the soil's surface. The authors also stated that $\mathrm{Pb}$ from road traffic is the primary contributor, with metallurgical production, immobile fuel combustion, and iron and steel fabrication playing a significant role. Phosphate fertilizers and waste incineration are two more primary sources of cadmium in the environment ${ }^{66}$. As a result, the prognosis for factor 1 of the geostatistical-based receptor models in the study area might be attributable to vehicular traffic and industrial sources $(\mathrm{Pb})$, while Cd Phosphate fertilizers. Barium occurrence is mostly a geogenic source even though it does not exist in nature but in diverse forms such as barium sulphate and barium carbonates ${ }^{67}$. However, barium occurrence in the study area is more of a geogenic source, and this has been corroborated by the mean, maximum and minimum values quantified (see Table 1). Iron (Fe) is ubiquitous. Its concentration is mostly controlled by geogenic sources, which is consistent with a report on urban soil pollution in Bangkok by Wilcke et al. ${ }^{54}$ who claim that Fe concentrations appear to be controlled by the parent material. Although most literature suggests that Fe can be found virtually everywhere, its excesses in higher levels in soil and the environment may be traceable to a point source (e.g., iron and steel industries). Reitner and Thiel ${ }^{65}$, Alloway ${ }^{57}$ and Schafer and Einax $^{68}$ hinted that the increased Fe concentrations in the environment and soil might be due to nearby industrial point sources producing iron-based substances such as iron and steel production, machine making, cast iron, wrought iron, and alloy as a significant source of Fe pollution in the environment. This correlates to the current situation in the study area, as evidenced by the presence of metal and steel industries. 
Factor 2 of the EBK-PMF receptor model recorded a 23.42\% variance in factor loadings, while the OK-PMF and PMF receptor models contributed $28.61 \%$ and $37.49 \%$, respectively. Ba (41.70\%) dominated factor 2 of the EBK-PMF receptor model, $\mathrm{Al}$ (46.20\%), $\mathrm{Cd}$ (41.00\%), and $\mathrm{Pb}$ (45.60\%) controlled OK-PMF, and $\mathrm{Al}(54.70 \%), \mathrm{Cd}$ (49.10\%), Fe (48.50\%), and V (50.40\%) influenced PMF (see Table 2). PMF discharged a lot of dominant PTEs in this factor loadings more than the geostatistical based receptor models. However, the sources of Ba, Fe and $\mathrm{Cd}$ have been discussed previously in factor 1 . Aluminum is ubiquitous and is mostly found in parent materials such as igneous rocks. According to Lantzy and Mackenzie ${ }^{69}$ and Exley ${ }^{70} \mathrm{Al}$ is a significant component of the earth's crust; natural weathering processes go far beyond discharges to air, water, and land linked to human activity. According to Atsdr ${ }^{71}$, Al occurrence in the soil and the environment is via weathering rocks and minerals. However, the author further suggested that the man-made activities that pollute $\mathrm{Al}$ in the soil and environment are industrial processes, water effluent and atmospheric deposition. This is in line with the presence of the metal industry in the study area that produces aluminum products such as aluminum fences, aluminum sheets in all sizes, perforated sheets etc. Vanadium is distributed extensively in the igneous and sediment rocks and minerals ${ }^{72}$. Nevertheless, it is economically important because it is employed mostly in the steel sector in alloy manufacturing. Moskalyk et al. ${ }^{73}$ and $\mathrm{Yu}$ et al..$^{74}$ outlined that vanadium reserves are discovered in mineral and hydrocarbon deposits worldwide, especially China, South Africa, and Russia, the biggest vanadium derivatives producers. The maximum vanadium value recorded is higher than the EAV threshold, implying that anthropogenic sources are augmenting the geogenic sources to elevate vanadium levels in certain areas of the study area near the steel plant.

Factor 3 of the EBK-PMF receptor model amassed $25.24 \%$ of the total variance in the factor loadings, whereas OK-PMF and PMF receptor models likewise accrued $20.75 \%$ and $23.18 \%$ of the total factor loadings, respectively. Factor 3 of the EBK-PMF receptor model was eclipsed by V (40.10\%), OK-PMF was overshadowed by $\mathrm{Pb}(59.80 \%)$, and PMF was dictated by Sb (48.20\%) (see Table 2). The sources of $\mathrm{V}$ and $\mathrm{Pb}$ in the study area have been discussed previously in factors 1 and 2. Antimony ( $\mathrm{Sb}$ ) is a hazardous PTEs that can be found in the environment. $\mathrm{He}^{75}$ outlined that many concerns have been raised about rising levels of Sb pollution in the environment, primarily because of anthropogenic activities and the widespread use of Sb compounds. When the measured concentration of $\mathrm{Sb}$ in the study area is compared to the WAV and EAV thresholds, it appears that the concentration is above the permissible limits. The high level of Sb in the environment and soil throughout the study area may be attributed to a variety of sources, including vehicular emissions for its use as a fire retardant in brake linings, waste disposal and incineration, fuel combustion, metal smelters, textiles, plastics, painting and coating industries. This is congruent with previous studies of Bradl ${ }^{76}$ and Tschan et al. ${ }^{77}$ who analyzed the origins and sources of PTEs in the soil and the environment.

Factor 4 of the EBK-PMF receptor model accounted for $26.83 \%$ of the total variance in the factor loadings. In contrast, OK-PMF and PMF receptor models likewise accumulated $23.60 \%$ and $20.67 \%$ of the total factor loadings, respectively. In factor 4, V (40.10\%) controlled the EBK-PMF receptor model whilst OK-PMF was dominated by $\mathrm{Al}$ (40.80), $\mathrm{Ba}(40.20 \%)$ and $\mathrm{V}$ (45.70\%), and PMF was dominated by $\mathrm{Pb}$ (49.90\%) (see Table 2). The dominant PTEs have been discussed in the preceding factor loadings. Although $\mathrm{Pb}$ obtained a high percentage contribution from the OK-PMF, the receptor model consistently projected $\mathrm{Pb}$ as the dominant $\mathrm{PTE}$ in different factors such as factor 1 for EBK-PMF, factor 3 for OK-PMF and factor 4 for PMF receptor models.

The spatial distribution of the PTEs in each factor loadings was determined using geographical weighted regression kriging (see Figs. 3 and 4) on factor scores of each receptor model against four environmental covariates (i.e., elevation, total catchment area, LS factor, and valley depth), and the spatial prediction maps were duly evaluated for prediction accuracy using the coefficient of determination $\left(\mathrm{R}^{2}\right)$. The receptor models displayed PTEs spatial distribution factor loadings hotspots for OK-PMF-F1 in the eastern area covering a more significant portion of the southeastern part of the map. Only EBK-PMF-F1 indicated patches of PTEs hotspots in the southeastern while both EBK-PMF-F1 and PMF-F1 hotspots were detected in the southwestern. OK-PMF-F2 and PMF-F2 maps shared similar patterns with PTEs distribution hotspots covering the northeastern to the southeastern part of the map. Nevertheless, the EBK-PMF-F2 map exhibited hotspots of PTEs in the southeastern sector of the map. The factor 3 maps of the receptor models also depicted massive spatial distribution hotspots for PTEs in the northwestern to the southwestern sector of the map for EBK-PMF-F3. However, the OK-PMFF3 and PMF-F3 maps displayed patches of hotspots for the PTEs in factor 3. Factor 4 spatial distribution maps indicated PTEs pollution in the northeastern to the southeastern map area for EBK-PMF-F4. In the opposite direction, PTEs pollution hotspots were displayed for the OK-PMF-F4 map. Nonetheless, PMF-F4 showed a patch of hotspots on the southeastern side of the map.

The $\mathrm{R}^{2}$ distribution maps for the receptor models displayed similar hotspots patterns for EBK-PMF- $\mathrm{R}^{2}$ and OK-PMF- $\mathrm{R}^{2}$ (see Fig. 5) and on the contrary PMF- $\mathrm{R}^{2}$ map exhibited hotspots in the northwestern and the southeastern part of the map. The mapping prediction efficiency of the factor scores of the receptor models suggested that the EBK-PMF receptor model $\mathrm{R}^{2}$ values were between 0.05 and 0.92 , whereas OK-PMF was between 0.09 and 0.76 and PMF was 0.18 and 0.55 . This indicated that the prediction efficiency of the EBK-PMF receptor model efficiency factor scores was up to $92 \%$ as against $76 \%$ for OK-PMF and 55\% for PMF receptor models, respectively.

Reasonability and reliability of the results. Table 3 shows the source contribution results of the receptor models. Despite the fact that the source contributions to each factor loading came from a variety of sources, the source contributions in the table are based on the most prevalent PTEs and their dominance in factor loading per receptor model. Furthermore, while the source contribution per receptor model may be similar, it was distributed across a wide range of factor loadings. Therefore, the computed source contribution per factor loadings are reasonable and dependable, and diverse sources that contributed to quantifying the percentage proportion of PTEs pollution may be identified and interpreted. The correlation coefficient $\left(\mathrm{R}^{2}\right)$, root mean square error 


\begin{tabular}{|l|r|r|r|r|r|r|r|r|r|r|r|c|}
\hline \multirow{3}{*}{ Sources } & \multicolumn{1}{|l|}{ EBK-PMF } & \multicolumn{1}{|c|}{ OK-PMF } & \multicolumn{1}{l|}{ PMF } \\
\cline { 2 - 16 } & F1\% & F2\% & F3\% & F4\% & F1\% & F2\% & F3\% & F3\% & F1\% & F2\% & F3\% & F4\% \\
\hline Geogenic & 16.15 & 9.58 & 20.89 & 10.50 & 6.86 & 20.18 & 3.93 & 24.71 & 16.12 & 4.35 & 15.00 & 0.71 \\
\hline Vehicular traffic & 13.76 & 25.44 & 18.63 & 0.96 & 22.39 & 0.15 & 11.85 & 24.35 & 41.64 & 0.52 & 4.22 & 12.72 \\
\hline Phosphate fertilizer & 6.94 & 13.91 & 6.29 & 28.82 & 24.39 & 20.48 & 8.40 & 0.36 & 0.39 & 3.91 & 8.38 & 26.29 \\
\hline Steel industry & 6.41 & 16.66 & 15.63 & 18.11 & 24.08 & 12.94 & 8.88 & 9.45 & 12.36 & 3.86 & 12.54 & 11.17 \\
\hline Atmospheric deposits & 24.43 & 10.80 & 0.00 & 21.52 & 0.00 & 20.08 & 41.18 & 0.00 & 0.00 & 2.35 & 12.98 & 35.27 \\
\hline Metal works & 16.09 & 12.26 & 15.86 & 12.95 & 16.84 & 8.94 & 19.21 & 13.45 & 11.19 & 1.42 & 30.37 & 13.85 \\
\hline Waste disposal & 16.21 & 11.35 & 22.71 & 7.14 & 5.44 & 17.23 & 6.54 & 27.68 & 18.31 & 4.01 & 16.51 & 0.00 \\
\hline
\end{tabular}

Table 3. Results from the different receptor models source contribution in each factor loadings.

\begin{tabular}{|c|c|c|c|c|c|c|c|c|c|c|c|c|c|}
\hline \multirow[b]{2}{*}{ Algorithm } & \multirow[b]{2}{*}{ Models } & \multicolumn{3}{|l|}{ Al } & \multicolumn{3}{|l|}{$\mathrm{Ba}$} & \multicolumn{3}{|l|}{ Cd } & \multicolumn{3}{|l|}{$\mathrm{Fe}$} \\
\hline & & $\mathbf{R}^{2}$ & RMSE & MAE & $\mathbf{R}^{2}$ & RMSE & MAE & $\mathbf{R}^{2}$ & RMSE & MAE & $\mathbf{R}^{2}$ & RMSE & MAE \\
\hline \multirow{5}{*}{ SVMR } & EBK-PMF & 0.968 & 0.113 & 0.083 & 0.996 & 0.043 & 0.036 & 0.981 & 0.092 & 0.071 & 0.978 & 0.097 & 0.072 \\
\hline & OK-PMF & 0.758 & 0.286 & \begin{tabular}{|l|}
0.158 \\
\end{tabular} & 0.932 & 0.157 & 0.085 & 0.994 & 0.047 & 0.037 & 0.988 & 0.064 & 0.052 \\
\hline & PMF & 0.947 & 0.188 & 0.133 & 0.999 & 0.046 & 0.038 & \begin{tabular}{|l|}
0.9 \\
\end{tabular} & 0.252 & 0.134 & 0.767 & 0.399 & 0.297 \\
\hline & & \multicolumn{3}{|l|}{$\mathbf{P b}$} & \multicolumn{3}{|l|}{ Sb } & \multicolumn{3}{|l|}{ V } & & & \\
\hline & & $\mathbf{R}^{2}$ & RMSE & MAE & $\mathbf{R}^{2}$ & RMSE & MAE & $\mathbf{R}^{2}$ & RMSE & MAE & & & \\
\hline \multirow{3}{*}{ SVMR } & EBK-PMF & 0.993 & 0.06 & 0.045 & 0.915 & 0.19 & 0.141 & 0.98 & 0.092 & 0.07 & & & \\
\hline & OK-PMF & 0.937 & 0.158 & 0.092 & 0.816 & 0.256 & 0.168 & 0.751 & 0.289 & 0.15 & & & \\
\hline & PMF & 0.846 & 0.323 & 0.195 & 0.931 & 0.21 & 0.161 & 0.957 & 0.166 & 0.103 & & & \\
\hline & & \multicolumn{3}{|l|}{ Al } & \multicolumn{3}{|l|}{$\mathrm{Ba}$} & \multicolumn{3}{|l|}{$\mathrm{Cd}$} & \multicolumn{3}{|l|}{$\mathrm{Fe}$} \\
\hline & & $\mathbf{R}^{2}$ & RMSE & MAE & $\mathbf{R}^{2}$ & RMSE & MAE & $\mathbf{R}^{2}$ & RMSE & MAE & $\mathbf{R}^{2}$ & RMSE & MAE \\
\hline \multirow{3}{*}{ MLR } & EBK-PMF & 0.873 & 565.369 & 464.727 & 0.993 & 1.131 & 0.899 & 0.995 & 0.05 & 0.039 & 0.986 & 573.108 & 463.86 \\
\hline & OK-PMF & 0.939 & 895.006 & 670.332 & 0.843 & 4.289 & 3.416 & 0.997 & 0.037 & 0.029 & 0.986 & 506.787 & 432.985 \\
\hline & PMF & \begin{tabular}{|l|}
0.888 \\
\end{tabular} & 1215.43 & 932.4 & 0.998 & 1.713 & 0.98 & 0.946 & 0.228 & 0.165 & 0.891 & 3324.77 & 2471.66 \\
\hline & & \multicolumn{3}{|l|}{$\mathbf{P b}$} & \multicolumn{3}{|l|}{ Sb } & \multicolumn{3}{|l|}{$\mathrm{V}$} & & & \\
\hline & & $\mathbf{R}^{2}$ & RMSE & MAE & $\mathbf{R}^{2}$ & RMSE & MAE & $\mathbf{R}^{2}$ & RMSE & MAE & & & \\
\hline \multirow{3}{*}{ MLR } & EBK-PMF & \begin{tabular}{|l|}
0.998 \\
\end{tabular} & 0.472 & 0.352 & 0.674 & 0.259 & 0.189 & 0.87 & 0.752 & 0.605 & & & \\
\hline & OK-PMF & 0.992 & 1.479 & 1.01 & 0.78 & 0.353 & 0.266 & 0.869 & 3.612 & 2.092 & & & \\
\hline & PMF & 0.959 & 3.357 & 2.344 & 0.975 & 0.151 & 0.105 & 0.86 & 3.754 & 2.204 & & & \\
\hline
\end{tabular}

Table 4. Assessment of receptor models via support vector machine regression (SVMR) and multiple linear regression (MLR).

(RMSE) and mean absolute error (MAE) of the performance of EBK-PMF/OK-PMF/PMF receptor models allocated by the algorithms indicates the reasonability and feasibility of the discovered source profiles or contributions in each factor loadings.

Model performance. The performance of the receptor models was evaluated using the support vector machine regression (SVMR) and multiple linear regression (MLR) algorithms (see Table 4). The validation and accuracy evaluation criterion used results demonstrated that the $R^{2}$ of both algorithms (SVMR and MLR) for the receptor models indicated that 5 of the $7 \mathrm{PTEs}\left(\mathrm{Al}, \mathrm{Ba}, \mathrm{Pb}, \mathrm{Sb}\right.$ and $\mathrm{V}$ ) had high $\mathrm{R}^{2}$ values ranging from 0.915 to 0.996 for SVMR and 0.870 to 0.998 for MLR (Al, Ba, Pb and $\mathrm{V}$ ). Thus, the EBK-PMF receptor model consistently had high goodness fit in 4 out of 7 PTEs for both algorithms applied. Furthermore, in both algorithms, four of the PTEs ( $\mathrm{Al}, \mathrm{Ba}, \mathrm{Pb}$ and $\mathrm{V}$ ) were consistently predicted to favor EBK-PMF receptor model. The marginal errors estimated for receptor models using the RMSE and MAE similarly suggested that the errors for EBK-PMF were significantly reduced for $\mathrm{Al}, \mathrm{Ba}, \mathrm{Pb}, \mathrm{Sb}$, and $\mathrm{V}$ employing the SVMR algorithm for both MAE and RMSE. The error was also considerably reduced for these PTEs ( $\mathrm{Al}, \mathrm{Ba}, \mathrm{Pb}$, and $\mathrm{V}$ ) for the EK-PMF receptor model using the MLR algorithm. Similarly, Al, Ba, Pb, and $\mathrm{V}$ had lower error levels in both algorithms consistently for EBK-PMF compared to PMF and OK-PMF. The high $\mathrm{R}^{2}$ values and low error levels were anticipated based on comparable results achieved by $\mathrm{Wu}$ et al. ${ }^{23}$ when comparing APCS-MLR and PMF receptor models. In comparison, the minimum $\mathrm{R}^{2}$ value reported by $\mathrm{Wu}$ et al. ${ }^{23}$ was 0.83 , whereas the minimum $\mathrm{R}^{2}$ reported in this current study is 0.87. Callén et al. ${ }^{78}$ comparative analyses in Spain suggested that PMF is optimal to UNMIX and APCS-MLR by comparing the computed $\mathrm{R}^{2}$ values and the marginal error of the PTEs when analyzed.

Moreover, the authors ${ }^{78}$ added that the increased input data requirements of PMF enabled better results to be produced than with the other two models. This is congruent with the results of this study since the raw data was 
interpolated for EBK-PMF and OK-PMF, in which the predicted data extracted for the source apportionment computation improved modelling efficiency whilst significantly lowering errors in source distribution computation. Similarly, Gholizadeh et al. ${ }^{20}$ concluded that the APCS-MLR model performed better than the PMF due to its prediction efficiency based on $\mathrm{R}^{2}$ measured values. The cumulative performance of the hybridized receptor models in this study compared to the parent model (PMF) suggested that while the receptor models discharged relatively high $\mathrm{R}^{2}$ values, the error accompanying each source apportioned to each PTE in Ok-PMF and PMF is higher than EBK-PMF in terms of algorithms used. This is consistent with similar results obtained by Callén et al. ${ }^{78}$, reporting that the $\mathrm{R}^{2}$ was quite good, the errors, which were always in excess, were quite significant. Thus, the high errors in the receptor models could have impacted the output of the model (e.g., uncertainty parameters) and the data quality. Conversely, Gupta et al. ${ }^{79}$ compared different kriging interpolation algorithms and concluded that EBK interpolation enhances efficiency and, at the same time, reduces errors.

Most soils, particularly urban soils, exhibit pollution, compaction, and soil sealing, as well as deposition and the removal or mixing of natural substrates ${ }^{80}$. According to Bullock and Gregory ${ }^{81}$, soil throughout the urban and peri-urban setting appears to be highly impacted by human influence and even anthropogenic activities (i.e. carried from different places). A diversity of anthropogenic activities metes out these impacts. For instance, the urban and the peri-urban environment has been heavily influenced by vehicular emissions, coal burning, demolition or refurbishing of buildings, disposal of waste, metallurgy and urban paint usage ${ }^{82}$. These expose humans to all kinds of health-related challenges, especially children come into contact with PTEs related substances that are taken through diverse pathways such as dermal, ingestion and inhaling. Agyeman et al. ${ }^{83}$ reported that children exposed to PTEs in the urban and the peri-urban environment are higher due to their mouth and finger practices. The distinctive physiological of the youngsters, the hypersensitivity of the growing vital organ and various chemical types of metal is further exacerbated by the toxicological consequences ${ }^{84}$. The robustness of a receptor model with high efficiency and minimal error computation level tends to expose the hotspots of sources of PTEs in the environment and apportion in percentagewise the contribution of PTEs. The hybridization of EBK to PMF has achieved a high level of efficiency and minimize error significantly. This study demonstrated the viability of using a hybridized geostatistical-based receptor model to locate and distribute PTE sources in urban and peri-urban soils by applying and validating the EBK-PMF receptor model.

\section{Conclusion}

One of the most efficient multivariate applications used to recognize the source pathways and apportion percentage contribution of PTEs in pollution-related determination is the application of receptor models. The study compared a parent receptor model PMF to hybridized geostatistical based receptor model OK-PMF and the EBK-PMF. The OK-PMF discharged more PTEs in each factor than the EBK-PMF and the PMF receptor model, respectively. Despite that, all the receptor models predicted PTEs distribution and identified respective sources in the study precisely and consistently. However, the validation and accuracy assessment computed using the $\mathrm{R}^{2}$, RMSE and the MAE via support vector machine regression and the multiple linear regression algorithms suggested that EBK-PMF was optimal for 5 out of the 7 PTEs analyzed using SVMR and 4 PTEs using MLR algorithms. Moreover, the errors estimated, and the prediction's efficiency also indicated that the EBK-PMF receptor model reduces that error margin significantly compared to the parent receptor model PMF and OKPMF. In another vein, the GWRK spatial distribution map coefficient of determination prediction efficiency computed also suggested that the EBK-PMF receptor models factor scores prediction efficiency is up to $92 \%$ as against $76 \%$ for OK-PMF and 55\% for the parent receptor model PMF. Therefore, this study recommends applying hybridized receptor model EBK-PMF in identifying the source pathways of PTEs and apportioning the percentage contribution of PTEs in a polluted environment.

Received: 8 August 2021; Accepted: 22 November 2021

Published online: 08 December 2021

\section{References}

1. Hu, W. et al. Source identification of heavy metals in peri-urban agricultural soils of southeast China: An integrated approach. Environ. Pollut. 237, 650-661 (2018).

2. Xu, D. M. et al. Contaminant characteristics and environmental risk assessment of heavy metals in the paddy soils from lead ( $\mathrm{Pb}$ )zinc (Zn) mining areas in Guangdong Province, South China. Environ. Sci. Pollut. Res. 24, 24387-24399 (2017).

3. Zang, F. et al. Accumulation, spatio-temporal distribution, and risk assessment of heavy metals in the soil-corn system around a polymetallic mining area from the Loess Plateau, northwest China. Geoderma 305, 188-196 (2017).

4. Fei, X., Lou, Z., Xiao, R., Ren, Z. \& Lv, X. Contamination assessment and source apportionment of heavy metals in agricultural soil through the synthesis of PMF and GeogDetector models. Sci. Total Environ. 747, 141293 (2020).

5. Hou, Q. et al. Annual net input fluxes of heavy metals of the agro-ecosystem in the Yangtze River delta, China. J. Geochem. Explor. 139, 68-84 (2014).

6. Qu, C. et al. China's soil pollution control: Choices and challenges. Environ. Sci. Technol. 50, 13181-13183 (2016).

7. Kombe, W. J. Land use dynamics in peri-urban areas and their implications on the urban growth and form: The case of Dar es Salaam, Tanzania. Habitat Int. 29, 113-135 (2005).

8. Keshavarzi, B., Najmeddin, A., Moore, F. \& Afshari Moghaddam, P. Risk-based assessment of soil pollution by potentially toxic elements in the industrialized urban and peri-urban areas of Ahvaz metropolis, southwest of Iran. Ecotoxicol. Environ. Saf. 167, 365-375 (2019).

9. Vázquez de la Cueva, A. et al. Spatial variation of trace elements in the peri-urban soil of Madrid. J. Soils Sediments 14, 78-88. https://doi.org/10.1007/s11368-013-0772-5 (2014).

10. Tume, P. et al. Distinguishing between natural and anthropogenic sources for potentially toxic elements in urban soils of Talcahuano, Chile. J. Soils Sediments 18, 2335-2349. https://doi.org/10.1007/s11368-017-1750-0 (2018).

11. Fei, X. et al. The association between heavy metal soil pollution and stomach cancer: a case study in Hangzhou City, China. Environ. Geochem. Health 40, 2481-2490 (2018). 
12. Huang, J. et al. A new exploration of health risk assessment quantification from sources of soil heavy metals under different land use. Environ. Pollut. 243, 49-58 (2018).

13. Lang, Y. H., Li, G. L., Wang, X. M. \& Peng, P. Combination of Unmix and PMF receptor model to apportion the potential sources and contributions of PAHs in wetland soils from Jiaozhou Bay, China. Mar. Pollut. Bull. 90, 129-134 (2015).

14. Jain, S., Sharma, S. K., Mandal, T. K. \& Saxena, M. Source apportionment of PM10 in Delhi, India using PCA/APCS, UNMIX and PMF. Particuology 37, 107-118 (2018).

15. Guan, Q. et al. Source apportionment of heavy metals in farmland soil of Wuwei, China: Comparison of three receptor models. J. Clean. Prod. 237, 117792 (2019).

16. Salim, I. et al. Comparison of two receptor models PCA-MLR and PMF for source identification and apportionment of pollution carried by runoff from catchment and sub-watershed areas with mixed land cover in South Korea. Sci. Total Environ. 663, 764-775 (2019).

17. Zhang, J. et al. Vehicular contribution of PAHs in size dependent road dust: A source apportionment by PCA-MLR, PMF, and Unmix receptor models. Sci. Total Environ. 649, 1314-1322 (2019).

18. Zhang, H., Li, H., Yu, H. \& Cheng, S. Water quality assessment and pollution source apportionment using multi-statistic and APCS-MLR modeling techniques in Min River Basin, China. Environ. Sci. Pollut. Res. 27, 41987-42000 (2020).

19. Agyeman, P. C. et al. Source apportionment, contamination levels, and spatial prediction of potentially toxic elements in selected soils of the Czech Republic. Environ. Geochem. Health 43, 601-620 (2021).

20. Haji Gholizadeh, M., Melesse, A. M. \& Reddi, L. Water quality assessment and apportionment of pollution sources using APCSMLR and PMF receptor modeling techniques in three major rivers of South Florida. Sci. Total Environ. 566-567, 1552-1567 (2016).

21. Lee, D. H., Kim, J. H., Mendoza, J. A., Lee, C. H. \& Kang, J.-H. Characterization and source identification of pollutants in runoff from a mixed land use watershed using ordination analyses. Environ. Sci. Pollut. Res. 23(10), 9774-9790 (2016).

22. Yuanan, H., He, K., Sun, Z., Chen, G. \& Cheng, H. Quantitative source apportionment of heavy metal(loid)s in the agricultural soils of an industrializing region and associated model uncertainty. J. Hazard. Mater. 391, 122244 (2020).

23. Wu, J. et al. Source apportionment of soil heavy metals in fluvial islands, Anhui section of the lower Yangtze River: comparison of APCS-MLR and PMF. J. Soils Sediments 20, 3380-3393 (2020).

24. Wang, D., Tian, F., Yang, M., Liu, C. \& Li, Y. F. Application of positive matrix factorization to identify potential sources of PAHs in soil of Dalian, China. Environ. Pollut. 157, 1559-1564 (2009).

25. Weather Spark. Average weather in Frýdek-Místek, Czechia, year round-Weather spark (2016).

26. Kozak, J. (ed.) Soil Atlas of the Czech Republic (Czech University of Life Sciences, 2010).

27. Vacek, O., Vašát, R. \& Borůvka, L. Quantifying the pedodiversity-elevation relations. Geoderma 373, 114441 (2020).

28. Norris, G., Duvall, R., Brown, S. \& Bai, S. Epa positive matrix factorization (pmf) 5.0 fundamentals and user guide prepared for the US Environmental Protection Agency Office of Research and Development, Washington, DC. Washington, DC (2014).

29. Bishop, T. F. A. \& McBratney, A. B. A comparison of prediction methods for the creation of field-extent soil property maps. Geoderma 103, 149-160 (2001).

30. Krivoruchko, K. Empirical Bayesian Kriging Vol. Fall (ESRI Press, 2012).

31. Samsonova, V. P., Blagoveshchenskii, Yu. N. \& Meshalkina, Yu. L. Use of empirical Bayesian kriging for revealing heterogeneities in the distribution of organic carbon on agricultural lands. Eurasian Soil Sci. 50(3), 305-311 (2017).

32. Brunsdon, C., Fotheringham, A. S. \& Charlton, M. E. Geographically weighted regression: A method for exploring spatial nonstationarity. Geogr. Anal. 28, 281-298 (1996).

33. Zhang, C., Tang, Y., Xu, X. \& Kiely, G. Towards spatial geochemical modelling: Use of geographically weighted regression for mapping soil organic carbon contents in Ireland. Appl. Geochem. 26, 1239-1248 (2011).

34. Kumar, S., Lal, R. \& Liu, D. A geographically weighted regression kriging approach for mapping soil organic carbon stock. Geoderma 189-190, 627-634 (2012).

35. Wang, K., Zhang, C. \& Li, W. Predictive mapping of soil total nitrogen at a regional scale: A comparison between geographically weighted regression and cokriging. Appl. Geogr. 42, 73-85 (2013).

36. Song, X. D. et al. Mapping soil organic carbon content by geographically weighted regression: A case study in the Heihe River Basin, China. Geoderma 261, 11-22 (2016).

37. Zeng, C. et al. Mapping soil organic matter concentration at different scales using a mixed geographically weighted regression method. Geoderma 281, 69-82 (2016).

38. Wang, Z. et al. Elucidating the differentiation of soil heavy metals under different land uses with geographically weighted regression and self-organizing map. Environ. Pollut. 260, 114065 (2020).

39. Vapnik, V. The nature of statistical learning theory. Technometrics 38, 409 (1995).

40. Li, Z., Zhou, M., Xu, L. J., Lin, H. \& Pu, H. Training sparse SVM on the core sets of fitting-planes. Neurocomputing 130, 20-27 (2014).

41. Cherkassky, V. \& Mulier, F. Learning from Data: Concepts, Theory, and Methods 2nd edn. (Wiley, 2006).

42. John, K. et al. Using machine learning algorithms to estimate soil organic carbon variability with environmental variables and soil nutrient indicators in an alluvial soil. Land 9, 1-20 (2020).

43. Vohland, M., Besold, J., Hill, J. \& Fründ, H. C. Comparing different multivariate calibration methods for the determination of soil organic carbon pools with visible to near infrared spectroscopy. Geoderma 166, 198-205 (2011).

44. Kooistra, L. et al. The potential of field spectroscopy for the assessment of sediment properties in river floodplains. Anal. Chim. Acta 484, 189-200 (2003).

45. Li, L. et al. Methods for estimating leaf nitrogen concentration of winter oilseed rape (Brassica napus L.) using in situ leaf spectroscopy. Ind. Crops Prod. 91, 194-204 (2016).

46. Huang, Y. et al. Heavy metal pollution and health risk assessment of agricultural soils in a typical peri-urban area in southeast China. J. Environ. Manag. 207, 159-168 (2018).

47. Hossain Bhuiyan, M. A., Chandra Karmaker, S., Bodrud-Doza, M., Rakib, M. A. \& Saha, B. B. Enrichment, sources and ecological risk mapping of heavy metals in agricultural soils of dhaka district employing SOM, PMF and GIS methods. Chemosphere 263, $12833(2021)$.

48. Linde, M., Öborn, I. \& Gustafsson, J. P. Effects of changed soil conditions on the mobility of trace metals in moderately contaminated urban soils. Water. Air. Soil Pollut. 183, 69-83 (2007).

49. Tume, P., Bech, J., Sepulveda, B., Tume, L. \& Bech, J. Concentrations of heavy metals in urban soils of Talcahuano (Chile): A preliminary study. Environ. Monit. Assess. 140, 91-98 (2008).

50. Wiseman, C. L. S., Zereini, F. \& Püttmann, W. Traffic-related trace element fate and uptake by plants cultivated in roadside soils in Toronto, Canada. Sci. Total Environ. 442, 86-95 (2013).

51. De Miguel, E., Izquierdo, M., Gómez, A., Mingot, J. \& Barrio-Parra, F. Risk assessment from exposure to arsenic, antimony, and selenium in urban gardens (Madrid, Spain). Environ. Toxicol. Chem. 36, 544-550 (2017).

52. Nadal, M., Schuhmacher, M. \& Domingo, J. L. Metal pollution of soils and vegetation in an area with petrochemical industry. Sci. Total Environ. 321, 59-69 (2004).

53. da Silva, E. B. et al. Background concentrations of trace metals As, $\mathrm{Ba}, \mathrm{Cd} \mathrm{Co}, \mathrm{Cu}, \mathrm{Ni}, \mathrm{Pb}$, Se, and $\mathrm{Zn}$ in 214 Florida urban soils: Different cities and land uses. Environ. Pollut. 264, 114737 (2020). 
54. Wilcke, W., Müller, S., Kanchanakool, N. \& Zech, W. Urban soil contamination in Bangkok: Heavy metal and aluminium partitioning in topsoils. Geoderma 86, 211-228 (1998).

55. Zhang, Q. et al. Distribution and contamination assessment of soil heavy metals in the jiulongjiang river catchment, southeast China. Int. J. Environ. Res. Public Health 16, 4674 (2019).

56. Ursínyová, M. \& Hladíková, V. Chaper 3 Cadmium in the environment of Central Europe. Trace Met. Environ. 4, 87-107 (2000).

57. Alloway, B. J. Sources of Heavy Metals and Metalloids in Soils 11-50 (2013). https://doi.org/10.1007/978-94-007-4470-7_2.

58. Negri, A. P., Harford, A. J., Parry, D. L. \& van Dam, R. A. Effects of alumina refinery wastewater and signature metal constituents at the upper thermal tolerance of: 2. The early life stages of the coral Acropora tenuis. Mar. Pollut. Bull. 62, 474-482 (2011).

59. Harford, A. J. et al. Effects of alumina refinery wastewater and signature metal constituents at the upper thermal tolerance of: 1. The tropical diatom Nitzschia closterium. Mar. Pollut. Bull. 62, 466-473 (2011).

60. Robinson, G. R., Larkins, P., Boughton, C. J., Reed, B. W. \& Sibrell, P. L. Assessment of contamination from arsenical pesticide use on orchards in the Great Valley region, Virginia and West Virginia, USA. J. Environ. Qual. 36, 654-663 (2007).

61. Heimbürger, L. E., Migon, C., Dufour, A., Chiffoleau, J. F. \& Cossa, D. Trace metal concentrations in the North-western Mediterranean atmospheric aerosol between 1986 and 2008: Seasonal patterns and decadal trends. Sci. Total Environ. 408, 2629-2638 (2010).

62. Ye, X. et al. Assessment of heavy metal pollution in vegetables and relationships with soil heavy metal distribution in Zhejiang province, China. Environ. Monit. Assess. https://doi.org/10.1007/s10661-015-4604-5 (2015).

63. Ying, L., Shaogang, L. \& Xiaoyang, C. Assessment of heavy metal pollution and human health risk in urban soils of a coal mining city in East China. Hum. Ecol. Risk Assess. 22, 1359-1374 (2016).

64. Zhang, X., Wei, S., Sun, Q., Wadood, S. A. \& Guo, B. Source identification and spatial distribution of arsenic and heavy metals in agricultural soil around Hunan industrial estate by positive matrix factorization model, principle components analysis and geo statistical analysis. Ecotoxicol. Environ. Saf. 159, 354-362 (2018).

65. Reitner, J. \& Thiel, V. Heavy Metals. Encyclopedia of Earth Sciences Series (2011) https://doi.org/10.1007/978-1-4020-9212-1_109.

66. Rama Jyothi, N. Heavy metal sources and their effects on human health. In Heavy Metals - heir Environmental Impacts and Mitigation [Working Title] (IntechOpen, 2020). https://doi.org/10.5772/intechopen.95370.

67. WHO, W. H. O. Mercury in Drinking-Water, Background Document for Development of WHO Guidelines for Drinking-Water Quality. Who vol. WHO/SDE/WS http://www.who.int/water_sanitation_health/dwq/chemicals/mercuryfinal.pdf (2005).

68. Schaefer, K. \& Einax, J. W. Source apportionment and geostatistics: An outstanding combination for describing metals distribution in soil. Clean: Soil, Air, Water 44, 877-884 (2016).

69. Lantzy, R. J. \& Mackenzie, F. T. Atmospheric trace metals: Global cycles and assessment of man's impact. Geochim. Cosmochim. Acta 43, 511-525 (1979).

70. Exley, C. Human exposure to aluminium. Environm. Sci. Process. Impacts 15, 1807-1816 (2013).

71. Atsdr. Toxicological Profile for Aluminum. ATSDR's Toxicological Profiles (2002) https://doi.org/10.1201/9781420061888_ch29.

72. Yang, J. et al. Current status and associated human health risk of vanadium in soil in China. Chemosphere 171, 635-643 (2017).

73. Moskalyk, R. \& Engineering, A.A.-M. Processing of Vanadium: A Review (Elsevier, 2003).

74. Yu, X. et al. Rhizobia population was favoured during in situ phytoremediation of vanadium-titanium magnetite mine tailings dam using Pongamia pinnata. Environ. Pollut. 255, 113167 (2019).

75. He, M. Distribution and phytoavailability of antimony at an antimony mining and smelting area, Hunan, China. Environ. Geochem. Health 29(3), 209-219 (2007).

76. Bradl, H. B. Chapter 1 Sources and origins of heavy metals. Interface Sci. Technol. 6, 1-27 (2005).

77. Tschan, M., Robinson, B. H. \& Schulin, R. Antimony in the soil-plant system-A review. Environ. Chem. 6, 106-115 (2009).

78. Callén, M. S., de la Cruz, M. T., López, J. M., Navarro, M. V. \& Mastral, A. M. Comparison of receptor models for source apportionment of the PM10 in Zaragoza (Spain). Chemosphere 76, 1120-1129 (2009).

79. Gupta, A., Kamble, T. \& Machiwal, D. Comparison of ordinary and Bayesian kriging techniques in depicting rainfall variability in arid and semi-arid regions of north-west India. Environ. Earth Sci. 76, 1-16 (2017).

80. Li, G., Sun, G. X., Ren, Y., Luo, X. S. \& Zhu, Y. G. Urban soil and human health: a review. Eur. J. Soil Sci. 69, 196-215 (2018).

81. Bullock, P. \& Gregory, P. J. Soils in the urban environment. Soils Urban Environ. https://doi.org/10.1002/9781444310603 (2009).

82. Wong, C. S. C., Li, X. \& Thornton, I. Urban environmental geochemistry of trace metals. Environ. Pollut. 142, 1-16 (2006).

83. Agyeman, P. C. et al. Health risk assessment and the application of CF-PMF: A pollution assessment-based receptor model in an urban soil. J. Soils Sediments https://doi.org/10.1007/s11368-021-02988-x (2021).

84. Chen, W., Hrudey, S. E. \& Rousseaux, C. Bioavailability in Environmental Risk Assessment (1995).

85. Kabata-Pendias, A. Trace elements in soils and plants. In Trace Elements in Soils and Plants, Fourth Edition (2011).

\section{Acknowledgements}

This study was supported by an internal Ph.D. grant no. SV20-5-21130 of the Faculty of Agrobiology, Food and Natural Resources of the Czech University of Life Sciences Prague (CZU). The support from the Ministry of Education, Youth and Sports of the Czech Republic (Project No. CZ.02.1.01/0.0/0.0/16_019/0000845) is also acknowledged. Finally, The Centre of Excellence (Centre of the investigation of synthesis and transformation of nutritional substances in the food chain in interaction with potentially risk substances of anthropogenic origin: comprehensive assessment of the soil contamination risks for the quality of agricultural products, NutRisk Centre).

\section{Author contributions}

P.C.A.: conceptualization, methodology, investigation, writing-original draft, writing-review and editing. J.K.: investigation, writing-review and editing. N.M.K.: investigation, writing-review and editing. L.B. data collection and supervision: R.V. data collection and proofreading. O.D.: investigation, writing-review and editing: All authors read and approved the final manuscript.

\section{Competing interests}

The authors declare no competing interests.

\section{Additional information}

Correspondence and requests for materials should be addressed to P.C.A.

Reprints and permissions information is available at www.nature.com/reprints. 
Publisher's note Springer Nature remains neutral with regard to jurisdictional claims in published maps and institutional affiliations.

(c) (i) Open Access This article is licensed under a Creative Commons Attribution 4.0 International License, which permits use, sharing, adaptation, distribution and reproduction in any medium or format, as long as you give appropriate credit to the original author(s) and the source, provide a link to the Creative Commons licence, and indicate if changes were made. The images or other third party material in this article are included in the article's Creative Commons licence, unless indicated otherwise in a credit line to the material. If material is not included in the article's Creative Commons licence and your intended use is not permitted by statutory regulation or exceeds the permitted use, you will need to obtain permission directly from the copyright holder. To view a copy of this licence, visit http://creativecommons.org/licenses/by/4.0/.

(C) The Author(s) 2021 